\title{
Rebranding Desa Wisata Kembang Arum untuk Meningkatkan Daya Saing Daerah di Bidang Pariwisata
}

\author{
Wibowo \\ Program Studi Desain Komunikasi Visual \\ FSR ISI Yogyakarta \\ wibowo_dkvisi@yahoo.com
}

\begin{abstract}
Tourism is one of the flagship programs of the Indonesian government. One of the tourism sector that is currently heavily promoted is a tourist village. Tourism Village Kembang Arum is a rural area that has some special characteristics that deserve to be a tourist destination. In this region the population still has a tradition and culture that is still relatively original. In addition, several supporting factors such as typical food, agricultural systems, and social systems also color a tourist village area.

Other problems identified in the initial study are: Lack of ownership and low community involvement, Packaging less attractive tour packages and "selling". Not yet realized the infrastructure that supports information technology. Lack of attractive promotions. aesthetic and communicative. Solutions to overcome the problem are: Need to rebranding Desa Wisata Kembang Arum to improve the image, credibility, and profesonalisme; Increased integrated promotion through conventional media and social media websites, webblogs, facebook, tweeter and instagram; All local potentials and features such as traditional food culinary, traditional arts, traditional game-based outbound are improved, and integrated in the Arum Tourist Village Tour package.
\end{abstract}

Keywords: Rebranding, tourist village, competitiveness

\section{PRAKATA}

Desa wisata adalah suatu bentuk integrasi antara atraksi, akomodasi dan fasilitas pendukung yang disajikan dalam suatu struktur kehidupan masyarakat yang menyatu dengan tata cara dan tradisi yang berlaku. Terdapat dua konsep yang utama dalam komponen desa wisata: yaitu akomodasi dan atraksi. Akomodasi merupakan sebagian dari tempat tinggal para penduduk setempat dan atau unit-unit yang berkembang atas konsep tempat tinggal penduduk. Sedangkan atraksi, adalah seluruh kehidupan keseharian penduduk setempat beserta setting fisik lokasi desa yang memungkinkan berintegrasinya wisatawan sebagai partisipasi aktif seperti: kursus tari, bahasa dan lain-lain yang spesifik.

Salah satu Desa Wisata yang sedang dikembangkan oleh Pemerintah daerah Kabupaten Sleman adalah: Desa Kembang Arum. Desa Wisata ini terletak di Desa Donokerto, Keca matan Turi, Kabupaten Sleman, Yogyakarta.

Desa wisata Kembang Arum menawar kan berbagai jenis keindahan lengkap dengan fasilitasnya. Desa wisata ini mengusung 
konsep desa wisata edukasi, dimana anakanak bisa belajar tentang seni, budaya dan lingkungan alam.

Desa wisata Kembangarum ini bisa juga disebut juga sebagai Desa Wisata Pendidikan karena para pengunjung yang datang di sini tidak saja menik- mati suasana dan keramah tamahan penduduk yang ada di desa itu. Namun pengunjung juga akan mendapat banyak pelajaran dan pengetahuan dari kunjungan wisata ini. Tidak sekedar menikmati kunjungan wisata saja, namun ada nuansa edukasi yang akan diperoleh di desa wisata ini.

Namun sayang berbagai prestasi yang melekat serta potensi yang demikian besar ini, masih belum didukung dengan upaya public relation, branding, dan positioning yang kuat. Sangat disayangkan, jika Desa Wisata Kembang Arum ini belum menjadi prioritas kunjungan wisata bagi wisatawan domestik maupun manca negara. Oleh karena itu perlu direncanakan dan dirancang Branding, Corporate identity, dan public relation yang professional.

\section{Desa Wisata Edukasi}

Desa wisata Kembangarum yang diresmikan pada pertengahan tahun 2005 ini menawarkan edukasi dan alam sebagai sajian wisata bagi pengunjung. Program-program yang dirancang dan dibangun di desa wisata ini mengedepankan edukasi atau pendidikan bagi anak-anak khususnya. Hal ini ditunjukkan dengan adanya sanggar lukis dan perpustakaan yang dibangun menarik untuk anak-anak. Perpustakaan dan sanggar lukis ini berada di dekat sungai dan taman sehingga menambah suasana sejuk di desa tersebut. Tentunya hal ini sangat diminati oleh anak-anak. Sebagai sarana pendidikan yang lain, desa wisata Kembangarum juga menyajikan berbagai sarana permainan tradisional tradisional seperti egrang, engklek, dakon, gobak sodor, dan lainnya.

Sungai di desa ini juga dijadikan sebagai sarana permainan. Sungai tersebut bukan merupakan sungai yang kotor dan tidak terawat, tetapi sengaja dirawat dan dibuat sebagai arena permainan. Kolam pemancingan ikan dan kolam renang alami merupakan arena bermain yang tidak kalah menarik.

\section{Sarana dan Prasarana yang Lengkap}

Beberapa Sarana dan Prasarana yang terdapat di Desa Kembangarum ini misalnya : tempat ibadah (Masjid), Homestay, Arena pemainan, Sanggar lukis, Perpustakaan wisata, Mobil untuk jelajah alam, Rumah makan.

Desa wisata Kembangarum memiliki luas 13 hektar sehingga banyak obyek dan 
arena permainan yang dapat disajikan di desa tersebut. Di desa wisata Kembangarum terdapat sebuah rumah yang dibangun khusus untuk para tamu dan penginapan. Rumah ini dibangun dari bambu, berlantai tanah, dan dihiasi dengan wayang dan lukisan-lukisan. Di depan rumah ini terdapat berbagai barang unik, seperti patung bambu dan kursi meja bambu. Di rumah ini pengunjung dapat memperoleh kenyamanan karena nuansa sejuk dari pemandangan dan suara gemercik air yang menenangkan. Rumah ini disewakan Rp. 750.000,00 per malam untuk rombongan. Pengunjung desa wisata Kembang arum dapat memperoleh keterampilan melukis dengan mengeluarkan biaya yang tidak terlalu mahal. Fasilitas yang diberikan adalah kain kanvas, cat lukis, dan dilatih cara melukis yang benar. Hasil lukisan tersebut dapat dibawa pulang oleh pengunjung. Begitu juga dengan batik tulis yang dapat dibawa pulang. Selain lukisan biasa, pengunjung dapat belajar batik tulis di desa wisata Kembangarum. per orang. Fasilitas lain adalah kuliner tradisional,. Tersedia 15 macam makanan tradisional dan makan besar seperti gudeg, brongkos, sayur lodeh, sego megono, dan lain-lain.

\section{Tinjauan Pustaka}

Terkait dengan penelitian ini, terlebih dahulu perancang telah melakukan penelitian dengan judul "Perancangan Media Komunikasi Visual Pelestarian Upacara Adat Daerah Istimewa Yogyakarta". Penelitian dan Perancangan tersebut menggambarkan/ menganalisa keterlibatan masyarakat secara komprehensif dengan tujuan untuk menemukenali pola-pola pemberdayaan masyarakat dalam menumbuhkan rasa memiliki terhadap tradisi dan upacara adat yangada di desanya. Dalam penelitian tersebut, diketahui bahwa pemberdayaan dapat dilihat melalui keikutsertaan masyarakat pada lima tahap kegiatan. Tahap pertama dimulai dengan tahap pengambilan inisiatif. Di sini masyarakat dikenalkan kepada program program kerja yang akan direncanakan yang bertujuan untuk meningkatkan potensi masyarakat. Masyarakat diingatkan dengan masalah semakin berkurangnya aktivitas Seni tradisi dan upacara adat di lingkungannya sehingga dapat memunculkan ide positif untuk mengatasi masalah tersebut. Selanjutnya dilakukan penelitian awal terhadap target audience masyarakat desa. Tentu saja ini dibutuhkan kerjasama dan keterlibatan masyarakat. 
Pada tahap pelaksanaan dilakukan pemetaan kebutuhan kebutuhan masyarakat dan media komunikasi yang biasa digunakan. Selanjutnya adalah tahap pegawasan dan evaluasi dalam peningkatan kualitas Pada tahap ini pelibatan tokoh/pemimpin masyarakat sangat penting karena wewenangnya sebagai perantara antara pemilik program peningkatan kualitas lingkungan dengan pelaksana dan masyarakat.

Dari penelitian tersebut dapat disimpulkan bahwa pemberdayaan masyarakat dalam peningkatan kesadaran masyarakat menjaga kelestarian seni tradisi mutlak diperlukan. Penerapannya dapat melibatkan berbagai komponen masya rakat baik perorangan, kelompok masyarakat, warga masyarakat desa maupun pemimpin desa dinas (formal) maupun non formal (adat). Kesimpulan dari penelitian ini akan digunakan sebagai pijakan awal perancangan rebranding desa wisata Kembang Arum. Teori yang digunakan sebagai acuan atau dasar dalam melakukan sebuah penelitian berdasarkan pengetahuan dan pandangan terkait yang sudah ada sebelumnya. Kemudian teori inilah yang nantinya dihubungkan dengan proses penelitian yang dilakukan oleh peneliti sesuai dengan topik penelitian yang telah ditentukan.

\section{Tujuan Dan Manfaat Penelitian}

Tujuan khusus dari penelitian ini adalah: Melakukan Perancangan Branding Desa Wisata Kembang Arum untuk Meningkatkan Daya Saing Daerah di Bidang Pariwisata. Sedangkan urgensi penelitian adalah terwujudnya citra dan krebilitas desa wisata melalui upaya rebranding yang profesional. Upaya ini akan menimbulkan rasa memiliki dan keterlibatan yang lebih mendalam dari masyarakat desa Kembang Arum Di bidang iptek-sosbud, penanganan promosi, dan pemasaran melalui mdia konvensional dan sosial media yang profesional, akan membuat desa wisataa Kembang Arum lebih dikenal, menjadi target wisata baru, dan pada akhirnya mampu meningkatkan daya saing daerah di bidang pariwisata.

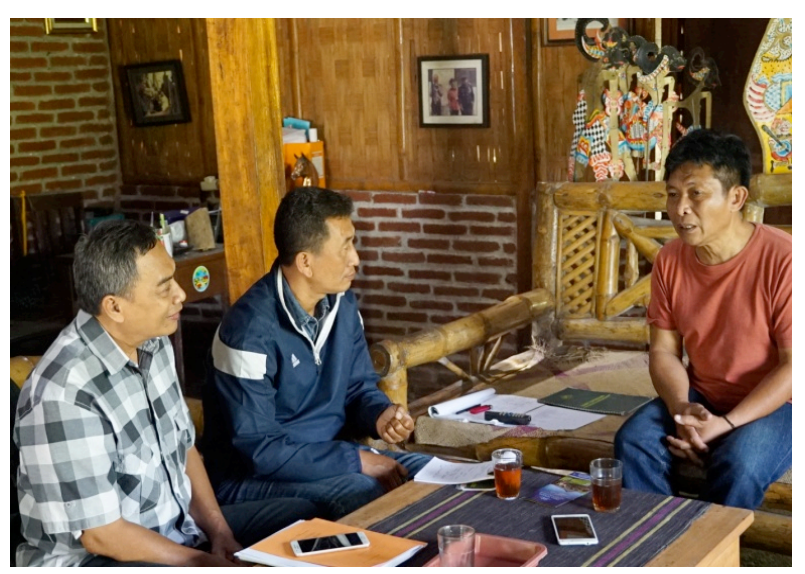

Gambar 1 Wawancara dengan Koordinator Pengelola Dewi Kembar, Bapak Herry Kustriyanto 


\section{Metode Penelitian}

Metode penelitian yang digunakan adalah metode Deskriptif Kualitatif. Tujuan dari penelitian ini adalah untuk mengungkapkan kejadian atau fakta, keadaan, fenomena, variabel dan keadaan yang terjadi saat penelitian berlangsung dengan mema parkan apa yang sebenarnya terjadi. Penelitian ini mengambil lokasi di desa wisata Kembang Arum yang terletak di Donokerto, Kecamatan Turi, Kabupaten Sleman, Provinsi Daerah Istimewa Yogyakarta. Desa wisata ini merupakan tempat wisata yang menyajikan keindahan alamnya dan suasana pedesaan yang masih sejuk dan asri, serta keramahtamahan penduduknya. Sasaran dalam penelitian ini adalah pengelola desa wisata Kembang Arum, Pemerintah Daerah Kabupaten Sleman, tokoh masyarakat yang meliputi kepala desa, dan ketua RT, Selain itu wawancara juga akan dilakukan kepada masyarakat sekitar yang akan dipilih secara acak. Pengkategorian ini didasarkan pada tujuan peneliti untuk memperoleh data yang lengkap dan objektif.

\section{Teknik Pengumpulan Data}

Data yang diperlukan dalam penelitian ini dikumpulkan melalui beberapa teknik. Teknik yang digunakan adalah:

\section{a. Kuesioner (Interview Guide)}

Penyebaran Kuestioner dilakukan pada 21 warga sekitar Desa Wisata Kembang Arum, yang dipilih secara acak. 5 orang diantaranya melalui "interview guide", (Kuesioner diisi oleh peneliti berdasarkan wawancara yang dilakukan secara langsung)

\section{b. Wawancara}

Teknik wawancara yang digunakan dalam penelitian ini adalah wawancara yang menekankan pada kekecualian, penyimpangan, penafsiran yang tidak lazim, penafsiran kembali, pendekatan baru, dan pandangan ahli.

Wawancara dilakukan kepada:

a. Pengelola Desa Wisata Kembang Arum, yang meliputi struktur kepengurusan dan data informasi 


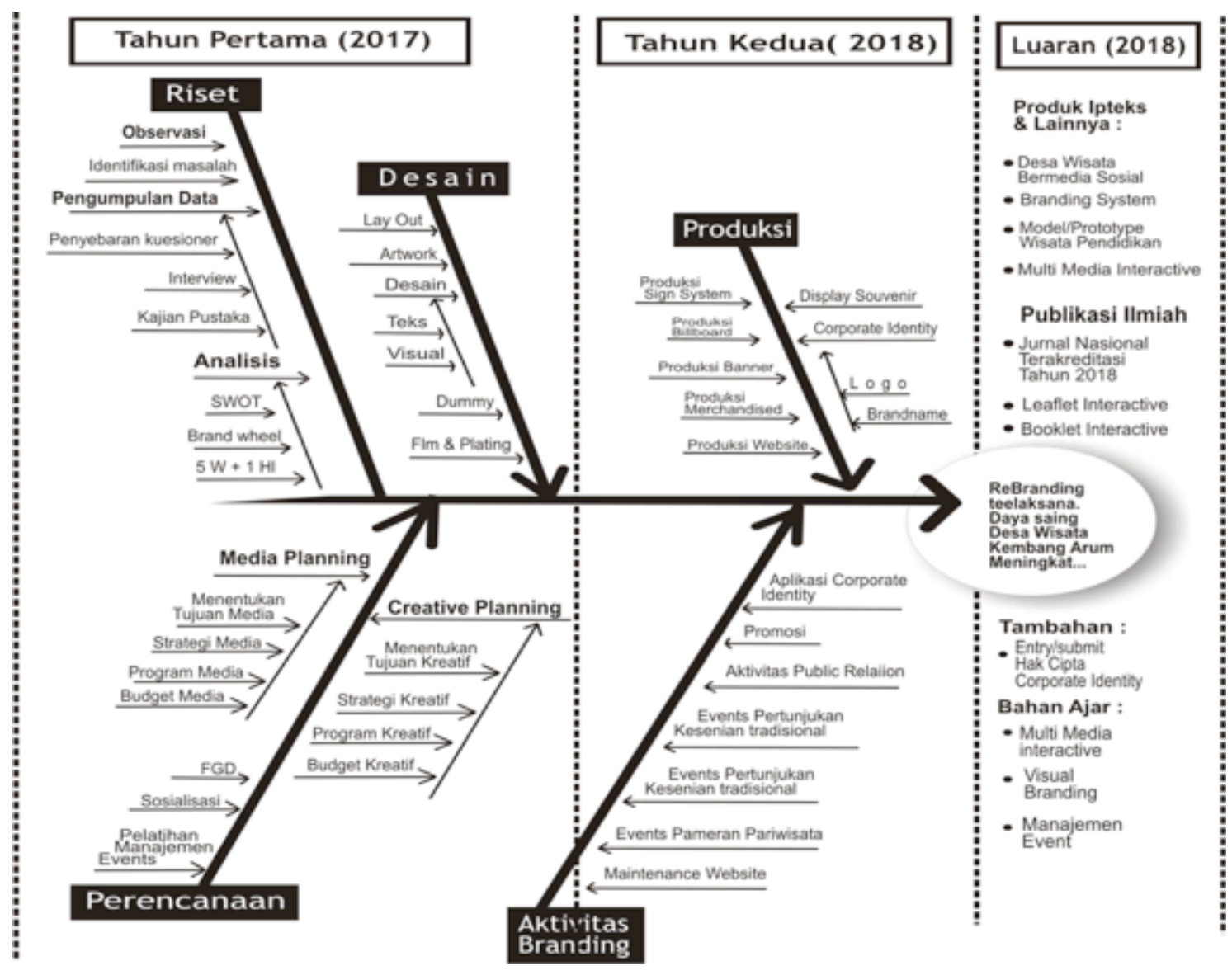

Gambar 2 Diagram Fishbone Pelaksanaan Program Rebranding

b. mengenai potensi apa saja yang dimiliki Desa Wisata Kembang Arum sehingga keberadaannya bisa memberikan manfaat bagi masyarakat sekitarnya.

c. Pemerintah Daerah Kabupaten Sleman, khususnya Departemen Pariwisata Kabupaten Sleman. Wawancara ini dilakukan untuk mengetahui bagaimana peranan pemerintah dalam memberikan dukungan terhadap pengembangan sektor pariwisata, melalui desa wisata dalam upaya untuk meningkatkan pemberdayaan masyarakat.

Tokoh masyarakat yang meliputi kepala desa, dan ketua RT. Wawancara ini dilakukan dalam rangka menggali informasi mengenai peranan desa wisata dalam memberdayakan masyarakat.Tokoh masyarakat ini dipilih karena dianggap yang mempunyai kekuasaan dan peranan penting dalam masyarakat.

Masyarakat Desa Kembang Arum, yang dipilih secara acak. Hal ini dilakukan untuk memperoleh informasi mengenai kontribusi 
apa saja yang telah mereka dapat dengan berubahnya status desa mereka menjadi desa wisata.

\section{c. Dokumentasi}

Data yang diperoleh selain berasal dari observasi dan wawancara juga akan memanfaatkan data dari buku, jurnal, skripsi, tesis, disertasi, surat kabar, internet, dan bahan lain yang relevan dengan studi ini.

Dalam penelitian ini data yang diperoleh melalui observasi dan wawancara akan diperlakukan sebagai data primer (data yang diperoleh langsung di lapangan), sedangkan data yang diperoleh melalui buku pengetahuan, surat kabar, dan internet akan diperlakukan sebagai data sekunder.

\section{Teknik Analisa Data}

Data yang telah diperoleh melalui observasi, wawancara, dan dari dokumentasi (buku, surat kabar, internet) akan diolah dan dianalisis.Analisis dilakukan melalui analisis SWOT (Strenght, Weakness, Opportunity dan Threat). Penelitian ini juga menggunakan metodologi Deskriptif kualitatif yang mengutamakan penyajian data dengan kalimat dan tidak bersifat angka-angka. Penelitian ini menampilkan hubungan secara langsung antara peneliti dengan responden karena ada interaksi. Data-data yang telah terkumpul kemudian diklasifikasikan menurut fokus penelitian untuk menjawab rumusan masalah, selanjutnya data-data tersebut akan dianalisis dengan teori-teori yang berhubungan dengan objek penelitian. Sebelum menentukan metode penelitian, perlu dipetakan dan diidentifkasi dahulu permasalahan yang ada pada Desa Wisata Kembang Arum. Permasalahan ini digambarkan sebagai sebab akibat dalam diagram Fishbone. Selanjutnya, dipaparkan solusinya, yaitu ReBranding Desa Wisata, juga dalam bentuk diagram Fishbone.

Setelah dipetakan permasalahan yang dihadapi Desa KembangArum, maka dapat diinventarisasi solusinya, yaitu Branding Desa Wisata Kembang Arum. Komponen utama dari Branding ini meliputi: Riset, Perencanaan, Desain (tahun pertama), dan Produksi serta Aktivitas Branding, pada tahun ke dua.

\section{Hasil dan Luaran Yang Dicapai}

Studi pendahuluan telah dilaksanakan oleh tim peneliti dengan melakukan observasi lapangan, melengkapi data verbal dan visual yang dibutuhkan dalam penyusunan proposal dan perencanaan. Data verbal misalnya wawancara kepada pemerintah desa, warga masyarakat dan pengelola desa wisata Kembang Arum. Data visual diperoleh dengan pengambilan gambar (foto) dari 
beberapa event (atraksi) wisata, agro wisata kebun salak, view, sideseeing serta topografi Desa Kembang Arum. Hasil observasi sementara, ditemukan beberapa kondisi baik fisik maupun nonfisik yang bisa menjadi modal dasar penelitian dan perancangan selanjutnya sebagai berikut:

\section{Potensi :}

- Sebagai lokasi wisata, Desa Kembang Arum terletak di daerah hamparanpegunungan yang sejuk, memiliki view dan sideseeing yang indah.

- Memiliki agro wisata kebun salak yang eksotik

- Memiliki beberapa grup kesenian tradisional dengan pemain warga setempat

- Memiliki banyak ragam kuliner tradisional yang khas Sleman dan siap saji

- Memiliki beberapa homestay dengan arsitektur tradisional

- Memiliki even outbond dengan fasilitas yang cukup lengkap.

Berdasarkan data tersebut dilakukan riset lanjutan dan perencanaan dengan hasil sebagai berikut:
- Survei Data Primer dan sekunder untuk mendapatkan data tambahan dari wawancara berupa data penduduk, sosial ekonomi dan pariwisata dari kelurahan.

- Melakukan Wawancara dengan Ketua pengurus Desa Wisata, Bpk Herry Kustriyanto(mendapat data mengenai sejarah Desa Wisata Kembang Arum, kegiatan seni pertunjukan (gamelan, jatilan), seni rupa, outbound, pentas Dewi Kembar, fasilitas yang dimiliki, rencana ke depan, dan sebagainya.

- Pengambilan gambar event dengan kamera fotografi dan video (mendapatkan Obyek wisata, kuliner, pertunjukan, pelatihan, pementasan "Dewi Kembar"

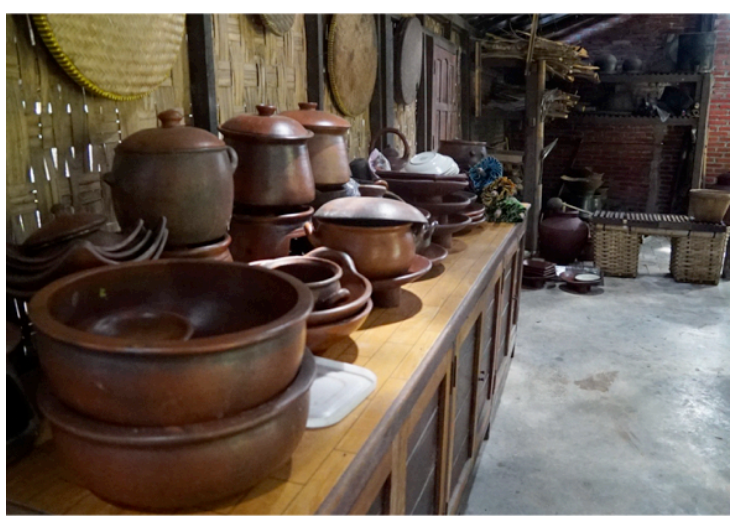

Gambar 3 Museum Dapur Tradisional Jawa di Desa Wisata Kembang Arum.

- Wawancara dengan warga sekitar obyek dan penyebaran kuesioner

- Penyebaran kuesioner II 
- Identifikasi data penelitian

- Tabulasi data penelitian

- Analisis Data Penelitian dan kesimpulan menggunakan analisis SWOT dan T-Plan

- Focus Group Discussion dengan Opinion Leader dan Pelaku kegiatan Desa

- Wisata dan PR untuk mendapatkan masukan mengenai media promosi

- Media Planning I dan II (membuat perencanaan media, untuk above the line dan below the line media)

- Creative Planning

- Sosialisasi I (Sosalisasi rencana program kepada warga sekitar dan mendapat masukan)

\section{Pembuatan Desain}

- Konsep dan Lay Out Desain Website

- Lay out Desain Corporate Identity

- Desain Corporate Identity dan aplikasi

- Lay out desain brosur dan leaflet

- Lay out \& desain Banner

- Lay out desain Merchandise

- Lay out \& desain Billboard

- Lay out dan Desain Sign system

- Penyusunan Buku Ajar "Visual Branding".
- Penyusunan Jurnal dan pendaftaran (submit) ke Jurnal terakreditasi "Rekam"

\section{Rencana Luaran HAKI}

Kegiatan awal dari Rebranding Desa Wisata Kembang Arum ini akan merancang Corporate Identity, yang akan didaftarkan hak ciptanya pada DJKI (Direktorat Jenderal Kekayaan Intelektual), Kementerian Hukum dan Hak Asasi Manusia, pada tahun 2018

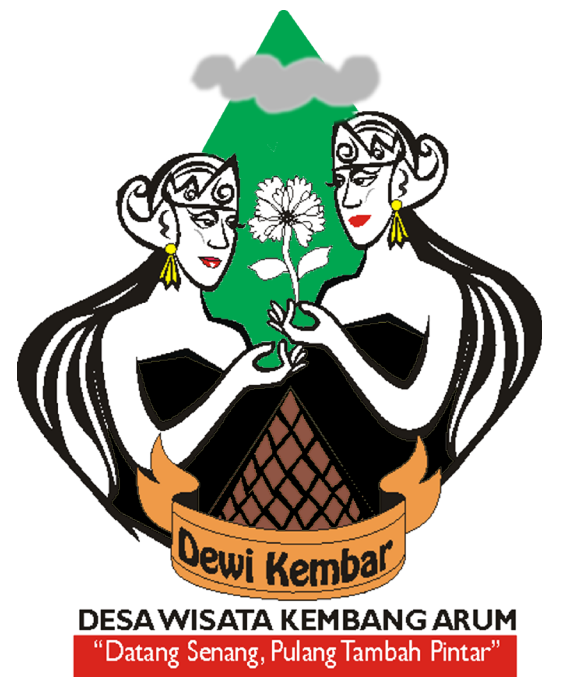

Gambar 4 Logo dan Branname yang dibuat oleh Tim Peneliti

\section{KESIMPULAN DAN SARAN}

\section{Kesimpulan}

Wisatawan yang berkunjung ke desa wisata Kembang Arum, tidak hanya sekedar bersenang-senang saja, namun juga bisa berinteraksi dengan masyarakat setempat yang tinggal di desa wisata tersebut. Desa wisata ini menawarkan keindahan alam, budaya lokal yang khas, dan interaksi antara 
wisatawan dengan masyarakat setempat.. Perkembangan desa wisata Kembang Arum semakin menun- jukkan kemajuan, hal ini ditunjukkan dengan semakin banyaknya wisatawan yang berkunjung di desa ini. Namun demikian, dalam kaitannya dengan pemberdayaan masyarakat, pengem bangan pariwisata khususnya desa wisata ini belum bisa dijadikan sebagai salah satu tolok ukur partisipasi masyarakat dalam kegiatan desa wisata. Padahal upaya untuk melibatkan partisipasi masyarakat dalam setiap kegiatan desa wisata yang berdasarkan kemampuan masing masing, sangat diperlukan dalam realisasi branding desa tersebut. Keterlibatan itu dimulai dari pembentukan, pelaksanaan, hingga pemeliharaan. Seharusnya pengelolaan desa wisata ini juga sepenuhnya dipegang oleh masyarakat.

Dengan adanya pelibatan (partisipasi) masyarakat dalam kegiatan di desa wisata maka secara tidak langsung hal ini merupakan suatu bentuk pemberdayaan masyarakat. Masyarakat dilatih untuk berinteraksi dengan orang lain, dan dengan banyaknya wisatawan yang datang akan memberikan penghasilan pendapatan tersendiri bagi masyarakat. Semua warga masyarakat memiliki hak yang sama untuk berpartisipasi dalam semua kegiatan wisata yang berlangsung di desa mereka.Bentuk pemberdayaan masyarakat Kembang Arum melalui pengembangan desa wisata adalah partisipasi masyarakat dalam pengembangan desa wisata. Dengan adanya partisipasi aktif dari masyarakat tentu akan melatih mereka dalam berinteraksi dengan orang lain. Melalui interaksi ini pengelaman dan pengetahuan masyarakat akan bertambah. Dengan memiliki banyak pengalaman dan pengetahuan tentu akan menciptakan suatu masyarakat yang memiliki sumber daya manusia yang berkualitas. Bentuk lain dari pemberdayaan masyarakat Kembang Arum adalah adanya sistem bagi hasil bagi masyarakat jika ada wisatawan yang berkunjung. Sistem bagi hasil ini ditentukan melalui kesepakatan bersama agar tidak menimbulkan kecemburuan sosial dalam masyarakat.

Walaupun bukan sebagai pendapatan utama namun hasil pendapatan dari desa wisata ini akan membantu masyarakat dalam pemenuhan kebutuhan sehari-hari. Secara tidak langsung, hal ini akan menimbulkan rasa memiliki (sence of belonging) dan rasa tanggung jawab (sence of ability) dari masyarakat terhadap desa wisata. Kedua kondisi inilah yang sebenarnya menjadi modal dasar bagi pembentukan citra (branding) desa wisata Kembang Arum. Namun demikian hal ini belum bisa terwujud 
di desa Kembang Arum. Partisipasi masyarakat masih terbilang rendah. Hasil penelitian yang dilakukan, baik melalui wawancara dengan pejabat setempat, warga, dan maupun pengelola desa wisata, menunjukkan bahwa masih perlu upaya rebranding (pembentukan citra yang kuat) bagi desa wisata Kembang Arum. Selanjutnya dilakukan beberapa langkah kegiatan yang merupakan prosedur kerja branding desa wisata, yaitu :

a. Melakukan perencanaan yaitu media planning (menentukan tujuan, strategi, program dan budgeting media), FGD, Sosialisasi program) dan Creative planning (menentukan tujuan, strategi, program dan budget creative). Creative planning ini kemudian ditindak lanjuti dengan penyusunan naskah, pembuatan desain untuk media komunikasi visual.

b. Langkah ini kemudian dilanjutkan dengan aktivitas branding, yang meliputi: public relation, promosi, pameran pariwisata, pembuatan dan aplikasi corporate identity

c. Sambil merencanakan kegiatan, mulai dirintis luaran dari kegiatan penelitian ini, yaitu: bahan ajar, hak cipta corporate Identity, jurnal nasional terakreditasi dan pembuatan model desa wisata bermedia sosial.

\section{Saran}

1. Beberapa catatan dari hasil penelitian yang menunjukkan masih rendahnya partisipasi atau keterlibatan masyarakat dalam kegiatan desa wisata, harus ditingkatkan. Salah satu caranya adalah memberikan harapan yang lebih besar kepada masyarakat, tentang prospek ke depan desa wisata. Jika desa wisata berkembang, maka pengunjung akan lebih banyak. Pemasukan dana akan lebih banyak diterima desa wisata. Namun pelayanan juga harus ditingkatkan. Artinya hal itu akan membutuhkan keterlibatan masyarakat lebih banyak, baik intensitas maupun kuantitas. Pelayanan terhadap wisatawan/pengunjung perlu ditingkatkan. Jika wisatawan puas, mereka akan menulis pengalamannya di medsos dan dari mulut ke mulut.

2. Karena lokasi desa wisata Kembang Arum agak terpencil maka sulit dijangkau dan kurang dikenal. Oleh karena itu butuh sign system yang merupakan papan penunjuk lokasi (eye pathway), dan harus 
komunikatif serta informatif (eye catching).

3. Untuk memperkenalkan program kegiatan desa wisata bagi target audience yang jauh, harus dibuat desain website dan media sosial yang lain yang kreatif.

4. Harus ada aktivitas branding activation, yang meliputi: public relation, promosi, pameran pari wisata, pembuatan dan aplikasi corporate identity, untuk mende katkan target audience dengan desawisata.

\section{DAFTAR PUSTAKA}

[1] Aaker, David, 1991, Managing Brand Equity; Capitalizing on the Value of Brand Name, Free Press, New York.

[2] Ardian, Danus, 2013Kampung Bahasa Sebagai City Branding Kota Pare Kediri", Surabaya: Sunan Ampel Press

[3] Costa Keller, L. 1993. How to manage brand equity. Jakarta: Gramedia Pustaka.

[4] David E. Carter, 1990, How to Improve Your Corporate Identity, Art DirectionBook Company, New York

[5] Made Heny U D, 2012 . Pengembangan Desa Wisata Berbasis Partisipasi Masyarakat Lokal di Desa Wisata Jatiluwih Tabanan, Bali", Yogyakarta, Jurnal Kawistara, Vol. 3, Nomer 2.

[6] Murdiyanto, E. 2011. "Partisipasi Masyarakat dalam Pengembangan
DesaWisata

Karanggeneng, Purwobinangun, Pakem, Sleman". Yogyakarta, Jurnal SEPA, Vol. 7. No. 2.

[7] Napoles, Veron. 1990, Corporate Identity Design. Van Nostrand Reinhold, New York.

[8] Sumartoto, A.R., 2009. Pengembangan Pariwisata Berbasis Masyarakat. Surakarta: Sebelas Maret University Press.

[9] Hadiwijoyo, S. 2012. Perencanaan Pariwisata Perdesaan Berbasis Masyarakat (Sebuah Pendekatan Konsep). Yogyakarta: Graha Ilmu.

[10] Syafi'i, Ahmad, 2015 Perencanaan Desa Wisata Dengan Pendekatan Konsep Community Based Tourism (CBT) Di Desa Bedono, Kecamatan Sayung, Kabupaten Demak,dalam Jurnal Ruang, Volume 1 Nomor 2, ISSN 1851-3881, halaman: 61-70 